\title{
CLARENDON'S EXILE AND THE ROLE OF PERSONALITY IN HISTORICAL EXPLANATION ${ }^{1}$
}

\section{D'Maris Coffman}

As others have noticed, Jonathan Steinberg's work is noteworthy for his embrace of methodological pluralism. Steinberg did not think that history had native methodologies, believing instead that historical writing derives distinctiveness from its discursive conventions and epistemological claims. ${ }^{2}$ He thus welcomed and embraced methods imported from the other social sciences. ${ }^{3}$ While I was in graduate school at Penn, he encouraged me to master social and critical theory as tools for interpreting the importance of historical findings to the concerns of the present, whilst reminding me that historical explanation must leave room for contingency and for what Chris Clark has called the 'irreducibility of personality'.

At the same time, Steinberg was fascinated with biography and life-writing, and his late-life masterpiece, Bismarck: A Life, followed on from his thirty-six lectures for the Teaching Company entitled European History and European Lives: 1715 to 1914. Unsurprisingly, in his long career, Steinberg was interested in more than just those figures whose thirty-five lives informed his short portraits, and the constraints of space and chronology precluded at least one figure of lingering attention - Edward Hyde, the first Earl of Clarendon, whose own pen portraits had first captivated Jonathan with the genre of short biography that reached its zenith with Leslie Stephen's Dictionary of National Biography. Clarendon held an appeal for Jonathan, especially during his years in Cambridge, where his friendships with Owen Chadwick and John Morrill helped him understand how the English Civil Wars could indeed be considered the last of the European wars of religion. ${ }^{4}$ Part of what held such fascination for Steinberg was the sense in which Clarendon (who for Steinberg was a kind of English Bismarck) could be said to be one of the forefathers of the modern Conservative party, 
despite having spent the 1670s in exile when the Whigs and Tories first emerged, in the wake of the Exclusion Crisis, as factional rivals and ideological enemies. Steinberg never had time to investigate this in detail, but he did suggest to me that surely part of the answer might lay in Clarendon's personality, which his literacy legacy, historical, autobiographical and personal, laid bare and later immortalized for his immediate contemporaries and for eighteenth-century consumers of printed editions of his works. Or, to put it another way, to understand how the English consumed Clarendon's politics, one has to understand how they consumed his life.

Edward Hyde, Earl of Clarendon, in his private life and his public career, proved one of the most formidable, surprising, enduring and ultimately tragic figures of seventeenth-century English politics. Nothing in his unremarkable, if relatively privileged, childhood as the third son of a Wiltshire country gentleman presaged a grandfather of two reigning queens, fatherin-law to James II and grandfather-in-law to William of Orange; the guardian of Charles II in exile and Lord Chancellor after the Restoration; and the author of the Declaration of Breda (1660) and his own celebrated History of the Great Rebellion. As a moderate royalist statesman, Sir Edward Hyde fought in vain to forge a compromise between crown and parliament during the Civil Wars; after serving as the architect of the Restoration settlement, the Earl of Clarendon emerged as Charles II's most powerful minister. To the Tory High Anglicans, Clarendon enjoyed an iconic stature even after his fall and subsequent exile. After its publication in the eighteenth-century, Clarendon's History became, in the judgment of Hugh Trevor-Roper, 'the historical bible of the Tory Party, of which the Hyde family remained the secular head and Oxford University the spiritual centre'.

As Steinberg observed in his own foray into the 'history wars', Clarendon was still read by modern historians for the 'quality of his thought'. ${ }^{6}$ Lionized by eighteenth-century Tories and 
maligned by nineteenth-century Whigs, Clarendon was, in the verdict of another modern scholar, an 'unparalleled historian of his times'. 7 Two relatively recent, widely reviewed scholarly monographs investigated dimensions of Clarendon's historical writings. ${ }^{8}$ Amongst intellectual historians, Perez Zagorin, John Pocock and John Bowle have each offered lengthy discussions of his polemical attack on Hobbes, A Brief View and Survey of the Dangerous and Pernicious Errors to Church and State in Mr Hobbes's Book, entitled Leviathan, published in 1676, two years after Clarendon's death. ${ }^{9}$

Before 2017, when Martin Dzelzainis took up the question in his own magisterial contribution to Philip Major's Clarendon Reconsidered, Clarendon's reputation as an essayist and moralist never garnered much attention. ${ }^{10}$ Dzelzainis built on his thirty-year-old scholarly article on Clarendon's religious writings; apart from Martine Brownley's introduction to the Augustan Reprint Society's publication of Two Dialogues: Concerning Education and Of the Want of Respect Due to Age, Clarendon's essays have received no more than a scant twopage treatment in John Mason's 1935 University of Pennsylvania dissertation in English literature, 'Gentlefolk in the Making'. ${ }^{11}$ No one would suggest these aptly named 'miscellaneous writings' be counted among his major works. But given Clarendon's iconic stature, what can we learn from reconsidering them and their publication history?

Clarendon's miscellaneous works were not available in print until $1727 .{ }^{12}$ In an eighteenthcentury political culture marred by intense factional rivalries and Jacobite tensions, the figure of the 'great earl of Clarendon' provided a rallying cry for the High Anglican Tory Party. Clarendon's ‘honest and warm Concern for Truth and Liberty [...] Spirit of Piety [...] Experience of Men [...] Good Sense and Politeness' became emblematic of the sort of cautious, moderate, conservative statesman, who would be guided not by explicit ideological principles but by principled consideration of circumstance. ${ }^{13}$ This 'historical philosophy', as 
Hugh-Trevor Roper described it in a lecture in 1974 on the 300th anniversary of Clarendon's death, 'nourished by deep intellectual roots, looks forward [...] to the philosophical historians of the future: to Hume, Burke, and Acton' ${ }^{14}$ In other words, Clarendon - because of who he was as much as what he actually said about education, manners or morals - helped shape what many Tories of successive ages thought they should believe.

The biographical details of Clarendon's life, his unusual position in Stuart court society, the stature of his historical writings, the specifics of the scribal and print publication history and possibilities opened by the choice of genre, all suggest that these works may be more profitably analysed through the lens of Norbert Elias's 'civilizing process' ${ }^{15}$ Here we have a case study that permits us to expose and interrogate those processes by which acculturation of the wider society occurs, both as imagined by Clarendon in his own dialogues and as actualized through their reception - a reception which, in scribal form, touched his family and friends, and in print, paralleled his reputation throughout Britain's long eighteenth century.

\section{I.}

Before exploring this argument in detail, it may be useful to review Clarendon's biography. His autobiographical Life of Edward, Earl of Clarendon and its continuation, written primarily to vindicate his public role and win his return from exile, was circumspect about the details of his private life. Clarendon offered an adequate portrait of his education and upbringing, enough to see the outlines of his family's origins as country squires. In contrast to the ideal he advances in his dialogue Concerning Education, he was educated at home by private tutors. But for the death of his two older brothers and the backing of his uncle, the Lord Chief Justice, Sir Nicholas Hyde, who noticed his nephew's discipline, work habits and frugality, he would have been destined for a career as a clergyman. ${ }^{16}$ After Oxford, where he 
took his Bachelor of Arts, he trained at the Inns at Court. In the wake of his uncle's death, he advanced his career by two strategic - if mutually affectionate - marriages (his first wife died of smallpox within a year of their marriage), through his participation with Bulstrode Whitlock in defending court culture against the attacks of William Prynne, and via his association with Viscount Falkland's Great Tew Circle and his friendship with Archbishop William Laud. ${ }^{17}$ As the political crisis of the 1640s deepened, Hyde's opposition to Puritan calls for 'Root and Branch' Reform - abolishing the episcopacy - drove him to the royalist camp.

Hyde's attempts - along with his friends from the 'Great Tew', Lucius Viscount Falkland and Sir John Culpepper - to guide Charles I towards a settlement, based upon an interpretation of the ancient constitution that rested on a limited monarchy and established episcopacy constrained by the rule of law, have been thoroughly analysed in the secondary literature. ${ }^{18}$ Both the nuances of their constitutional thought in their authorship of the King's Answer to the Nineteen Propositions and the wider importance of sociability and conviviality in the formation of political faction have also been closely studied. ${ }^{19}$ Historians, aided by the accounts in his History and Life, have reconstructed his guardianship of Charles II in exile, Hyde's travails on the continent and his role in the Restoration. ${ }^{20}$ Although Clarendon was praised, even by his political opponents, for his actual conduct of office as Lord Chancellor, his policies met resistance from both those hard-line royalists whom the king short-changed in his Act of Oblivion and former parliamentarians whose religious and political sensibilities called for closer ties to Holland and greater toleration of dissent. In short, Clarendon's attempt to forge the English via media offended those on both sides. Historians may still debate the extent to which he unfairly took the blame for the failures of the Cavalier parliaments, the unpopular Clarendon Codes against religious dissenters, the catastrophic prosecution of the second Anglo-Dutch War and the sale of Dunkirk to France, but by 1667 
his political career was over. His wife's death in August offered a pretext for his resignation, but the real surprise came when Charles II did nothing to prevent the impeachment proceedings in October and even encouraged him to flee into exile. ${ }^{21}$

Unfortunately for the king's attempt to sacrifice his minister to secure a compromise with his new parliament, Clarendon had both the support of his son-in-law, the Duke of York, a substantial contingent in the House of Commons and many in the House of Lords. In the procedural squabbles that followed, it became apparent that the king might prorogue parliament and send him before the court of the Lord Steward, a probable death warrant. At the king's urging, Clarendon fled, hoping to return, but within months found himself banished for life despite the king's assurances that would not come to pass. His family and friends were forbidden to contact him under penalty of treason, a ban that was only lifted five years later, at the very end of his life. His two elder sons, Henry and Laurence, both members of parliament themselves, were left to mount his defence. Of the two, Laurence, the younger and more capable, inherited his father's mantle; he also served as editor of his father's historical works. Laurence Hyde's successful political career offers one indication that Clarendon was widely understood by contemporaries to be the victim of an unscrupulous king. The Hyde family was not disgraced nor did the brothers lose their influence at court. Laurence, at least, suffered greatly under this irony, eviscerating himself in a self-lacerating meditation upon the first anniversary of his father's death in 1674 for having urged his father to leave, but most of all for having given the appearance of

making myself well at court upon the ruins of my father's fortune, of which I had the good fortune not to be suspected, though I had given occasion enough for the suspicion; but out of mistaken policy that this [exile] would put an end to all, and after this sacrifice to their fears they would betake themselves to some other more public business, and leave our poor family to the privacy and inconsiderable condition to which [his enemies] had reduced it. ${ }^{22}$ 
Those sentiments - the keen sense of having somehow betrayed his father, especially on the heels of his mother's death, the desire for privacy and the embarrassment at his fortunes may, along with Clarendon's last will, explain why the most private and intensely personal of his father's writings did not appear in print until more than fifteen years after Laurence Hyde's death. They also suggest something of how, in the absence of specific instructions to children, such apparently 'literary works' can serve to help discipline the values and standards of an elite family even after their author's death. ${ }^{23}$

\section{II.}

Upon his exile, Clarendon left three grown and two minor children in the British Isles. The eldest three, Anne (Duchess of York), Henry and Laurence had already established themselves. A third son, Edward, had died in 1665 at the age of twenty; two other sons, another Edward and a Charles, did not survive early childhood. The youngest two children, Frances (1658-1723?) and James (1660?-1682), were only nine and seven years old respectively. They were left to their two older brothers' care. By Clarendon's death in 1674, he could but 'likewise recommend their sister Frances Hyde, and their brother, James Hyde, to their kindness, to whom I am able to leave nothing but their kindness'. In the same will, he bequeathed

to my said [elder] two sons all my papers and writings of any kind what soever, and leave them entirely to their disposal, as they shall be advised, either by suppressing or publishing, by the advice and approbation of my Lord Archbishop of Canterbury, and the Bishop of Winchester, whom I do entreat to be the overseers of this my will. And that they would both be suitors to his Majesty on my children's behalf, who have all possible need of his Majesty's charity, being children of a father who had never committed fault against his Majesty. ${ }^{24}$

These two items form nearly the entirety of the barely two-hundred-word document, which constituted the sum of Clarendon's instructions to his heirs. In a sense, the two issues - the sufferings and fates of his two youngest children and the publication of his literary works - 
were intertwined. In the records of their dispositions, there is enough material to permit speculation about the scribal publication of their father's miscellaneous works.

The two custodians, Gilbert Sheldon and George Morley, the archbishop of Canterbury and the bishop of Winchester, respectively, were Clarendon's friends from before the Civil War. The three were of similar social backgrounds; each had risen to influence and power through the Restoration. They were among the last surviving members of Falkland's Great Tew circle and were staunch royalists and tireless supporters of the established church. ${ }^{25}$ Sheldon died in 1677. His protégé William Sancroft, also a close Hyde family associate and client, succeeded Sheldon to the post of archbishop of Canterbury. Morley, meanwhile, had cause to take Clarendon's trust seriously; as dean of the chapel royal in the 1660 s, he was widely held to be responsible, by almost everyone except her father, for failing to prevent the late Anne, Duchess of York, from converting to Popery. ${ }^{26}$ Together, Morley and the newly appointed Sancroft made a credible, if vain, effort in 1679 to avert the Exclusion Crisis by attempting to 'recover' the Duke of York from his own Catholicism. ${ }^{27}$ With his sister-in-law Frances, the religious question, although politically insignificant, was just as grave a matter to her relatives.

Almost nothing survives of Lady Frances's childhood. She may have been close to her sister, the Duchess of York, who died of what was probably breast cancer in 1671 after the birth of her eighth child. At seventeen, Lady Frances married Thomas Keightley, gentleman usher to the Duke of York (the future James II). Keightley also, if only temporarily, converted to Catholicism while in York's service. This did not, however, impair Keightley's relationship with his Protestant brothers-in-law, devout High Anglicans to the end. Years later, Laurence Hyde's refusal of James II's demands to convert to Catholicism resulted in the loss of his post of Lord Treasurer in $1686 .^{28}$ These were the sorts of trials their father had feared for 
them in 1670 in his lengthy and touching dedication to his children, appended to his meditations on the psalms, which had been written years earlier during his first exile to Jersey during the Civil Wars. ${ }^{29}$ After their marriage, the couple emigrated from England to Ireland, where Keightley began a long career in the Irish service. They too had eight children, seven sons and one daughter, of whom only the daughter survived childhood to marry and have a family of her own. Lady Frances, consumed first by alcohol and then by religious doubts, was permanently estranged from her husband by 1693 after the death of her last surviving son. His brothers-in-law took her husband's side in the affair, blaming her temper. At their requests, she retreated to Glaslough in 1686, where she met her husband's friend Charlie Leslie, the controversialist and later non-juring polemicist, and his brother. With these clergymen and their wives, she travelled without her husband to the Isle of Wight in 1689, where she remained for some years. ${ }^{30}$ At least one author attributed Leslie's 'Short and Easie Method with the Deists' of 1698 to his attempts to minister to her doubts. ${ }^{31}$ This 'unhappy and unfortunate woman', as her brothers called her in their letters to one another, outlived all her siblings. Her religious doubts, if she had looked to her father's writings to assuage them late in life, may well be the only reason the miscellaneous works survived and did not perish in the fire that consumed the family's suburban seat in New Park, Petersham, in October $1721 . .^{32}$

The verdict of Clarendon's first biographer, Thomas Lister (a noted early nineteenth- century novelist and man of letters), in his Life and Administration of Edward, First Earl of Clarendon, appears quite plausible. In his piecemeal discussion of Clarendon's miscellaneous literary works, issued in 1815 by the same publisher as his own book, Lister did not notice the dialogues separately. Instead, noting the essays as uncharacteristic of the genre, he questioned whether or not 'Lord Clarendon's Essays were originally intended for publication' outside the family. ${ }^{33}$ Lister took great pains to argue for their informal style, pointed to 'much 
that was trite and common-place', but concluded they were 'indisputably such as could have proceeded only from a richly stored and very reflective mind'. The essays covered every topic imaginable: happiness, impudent delight in wickedness, drunkenness, envy, pride, anger, patience in adversity, contempt of death, friendship, counsel and conversation, (keeping) promises, liberty, industry, sickness, patience, repentance, conscience, the active and contemplative life, war, peace, sacrilege, reverence due antiquity and religious controversies. ${ }^{34}$ They were characterized by what Lister saw as the 'diffuseness which belongs especially to the fluent pen of a hasty writer'. ${ }^{35}$ Two hundred years later, we might say they appeared nothing so much as therapeutic to their author. But not, in other words, works intended to be published outside the author's family and friends. ${ }^{36}$

While it remains unclear what Sancroft and Morley thought of the writings or how Frances Keightley understood her father's admonitions, a few tokens of Laurence Hyde's engagement with his father's work survive. Laurence relied upon his father's words for guidance and consolation. In his private meditation, he wrote movingly of 'the memory of the best of fathers, and the kindest and wisest friend I ever met with: according to whose counsels I pray God I may regulate my actions, and live and die according to his practices, in imitation of his virtue and honesty towards man'. He reminisced about seeing his father in the last years of his exile, 'wherein he was pleased to discourse with me on several actions of his life, more like a friend, and upon more equal terms, than like a father, and gave me the perusal of several of his writings, wherein his mind might yet be more clearly discerned' ${ }^{37}$ In his care of his younger brother, he had apparently read his father's two dialogues and essays and internalized their advice. To Laurence, after Henry's dismal failure at the task, fell the burden of rescuing their youngest brother, James, from a life of despondent profligacy. ${ }^{38}$ Laurence's assessment, consciously or not, almost duplicates his father's analysis in his dialogues Concerning Education about the perils of Oxford and the Middle Temple for the less than 
studious, the risks and merits of travel abroad and the necessity that he and Henry 'always appear to be him to be of a mind'. ${ }^{39}$ Laurence's interventions appeared to have succeeded. They nonetheless ended tragically with Lieutenant James Hyde's drowning in the wreck of the Gloucester, where he apparently played a heroic role in saving the other passengers, including the Duke of York. In his last letter to his brother, a week before his death, James showed himself a junior partner in the family patronage network, offering an 'account of Sir John Berreyes' extreme diligence [...] who has desired me to present his most humble service to you' ${ }^{40}$ The upbeat tone of reportage suggested a young man who had, at last, found his feet. After the lieutenant's death, the Duke of York consoled Laurence: 'I am really troubled for the loss of your brother James. Really he would have made a very good man; for besides his other good qualities, he was as unconcerned as any man I ever saw, and all they who got off after me said the same thing. ${ }^{41}$ Although the younger Hyde had a low opinion of the ship's commander (a claim evidently borne out by the wreck), Captain Berry himself conveyed 'the great grief and sorrow [that] I have for the loss of Lieutenant and your Lordship's brother, who, I believe, would have been the best officer in his Majesty's Navy, if he had lived' ${ }^{42}$ The point, of course, is not to rehash these details for their own sake, but rather to show how, despite his brother's fears that he would harm their reputations, James Hyde's short life neatly encapsulated the values and norms promoted by their father.

In short, if Clarendon's miscellaneous works circulated before the eighteenth-century, they were confined to the social, familial and patronage networks of the Hyde family. Laurence Hyde, Earl of Rochester, as First Lord of the Treasury and later Lord Treasurer, was, even more than his older brother, at the centre of the family system. This model of distribution conforms to Harold Love's notion of scribal publication in the 'weak sense': 'publishing as a surrender of control over the future use of the manuscript constitutes our weak definition, the only additional condition being that the surrender should take place in a context where there 
was some practical likelihood of the text entering the public channels of communication' ${ }^{43}$ Clarendon's will met that standard. If copies were made by Laurence Hyde, Sancroft and his circle, Charles Leslie or Lady Frances Keightley, they were what Love dubbed 'user publications', i.e., for the reader's own use. ${ }^{44}$ Unfortunately, nothing more can be said with any certainty.

III.

The evidence for scribal publication has proven both elusive and inconclusive. What material survives points to the role of Clarendon's meditations on the psalms, his essays and the dialogues in equipping his ablest son with the means to socially discipline his family. Despite some noted peculiarities, reconstruction of the history of the publication of the dialogues was far more straightforward. The numbering of the editions is among these irregularities. As related by Dzelzainis, the dialogues were first published in 1727, appearing under three separate titles and two separate publishers in that year. ${ }^{45} \mathrm{~T}$. Woodward of Fleet Street and John Peele of Paternoster Row, a 'very considerable bookseller', ${ }^{46}$ offered two folio printings, one entitled 'A collection of several tracts of the Right Honourable Edward, Earl of Clarendon' ${ }^{47}$ and another, in all respects identical except for the title page, as 'A collection of several tracts of the Right Honourable Earl of Clarendon' ${ }^{48}$ Both printings contained the same pagination error. In the same year, J. Wilford included them as an appendix to an octavo edition of Clarendon's History of the Rebellion, entitled 'A Collection of Several Valuable Pieces of the Right Honourable Earl of Clarendon'. ${ }^{49}$ In 1747 and again in 1751, the Woodward and Peele 1727 edition was re-issued under different titles. The 1747 edition, entitled 'A Compleat Collection of Tracts by that Eminent Statesman the Right Honourable Edward, Earl of Clarendon', was printed by a group of five well-known printers: Charles Davis of London and his nephew Lockyer Davis, Stephen Austin of London, Samuel Baker (founder of Southeby's) and John Whiston of London. ${ }^{50}$ As Dzelzainis reports, these were 
unsold stock which Woodward and Peele had kept for two decades before selling on for publication with different cover sheets by the new group. ${ }^{51}$

In 1751, a separate and apparently unrelated printer, Samuel Paterson, using the same stock and similar red and black ink to that which adorned the 1747 title page, produced the 'Miscellaneous Works of the Right Honourable Edward, Earl of Clarendon'. 52 Again, how the stock came into Paterson's possession remains unclear; like Baker, Paterson too was an auctioneer. ${ }^{53}$ He labelled the 1751 printing the second edition, presumably after the 1747 one, which had an equally fine binding. Paterson's edition formed the basis for the Augustan Reprint Society edition of the dialogues in 1984. The so-called 'second' edition was the last ‘complete' collection of Clarendon's miscellaneous works. Afterwards, prospective publishers treated them by genre: the dialogue, the devotional writing and the contemplative essay.

In 1764 and 1765, respectively, Robert Urie of Scotland reprinted, as octavos, 'A Dialogue Concerning Education' and 'A Dialogue, on the want of respect due to age' separately from the rest of the collection. ${ }^{54}$ Robert Urie was known primarily for his publications of literary works. ${ }^{55}$ In 1796, in octavo form, a collection entitled the 'Moral Beauties of Clarendon' extracted the psalms from the earlier compilation. ${ }^{56}$ In 1815 Clarendon's essays appeared as 'Essays Moral and Entertaining, on the Various Faculties and Passions of the Human Mind, by the Right Honourable Edward, Earl of Clarendon', which borrowed its title from the table of contents of the 1747 edition. ${ }^{57}$ This collection, also in octavo, purported to be a companion to a collection of essays by Lord Bacon. Five years later, in 1820, the two were spliced together in a North American octavo edition entitled 'Essays by Lords Bacon and Clarendon. Two Volumes in One'. The North American edition further abridged the collection. ${ }^{58}$ In the preface, the editor informed the audience: 'it has been thought proper to omit three [of the 
essays], which, from their extreme length, rather claim to be considered as dissertations'.59 These three - 'On an active and contemplative life, and when one ought to be preferred to another', 'Of the reverence due antiquity' and 'Against the multiplying of controversies, by insisting upon particulars that are not necessary to the point in debate' - had been included in the 1815 edition. Given Clarendon's religious politics and Anglican sympathies, these three essays may have even been offensive to a nineteenth-century Boston audience.

IV.

Over the course of the seventeenth and eighteenth centuries, Clarendon's miscellaneous writings became available to a wider audience. Scribal publication was confined to the network of family and friends; early print publication largely took the form of expensive folio editions, only to be followed by reprintings in affordable octavo form in the late eighteenth and early nineteenth centuries, as Clarendon became enshrined as the grandfather of the Tory Party. In the social disciplining of his family, Clarendon's writings served to reinforce, at different times and with different members, the virtues of Christian piety, forbearance, discipline, courage in the face of adversity and death, witty conversation, friendship and sociability, learned disposition and deference to authority. While these were not necessarily the values of the Stuart royal courts, they played well with the dominant ethos of the Revolution settlement, with the English via media and the elites who ensured its survival.

Nothing in Clarendon's dialogue Concerning Education suggested a systematic program for education. Instead - and this is what both Brownley and Mason missed - what Clarendon did, in the form of a dialogue, was to work through the available educational opportunities and to suggest how 'persons of quality' might choose amongst them for their own children. Clarendon's six characters nicely cover the range of occupations open to elites in the late seventeenth-century British Isles - a lawyer, courtier, soldier, alderman, country gentleman 
and bishop. The other dialogue, Of the Want of Respect Due Age (in which the bishop does not appear), argued that parents have only to blame poor education of youth for lack of respect in old age. Although his characters put much of the blame on too great an enthusiasm for French fashion and custom, Clarendon did not use them as voices to rail against the youthful enemies who had secured his expulsion from office and court. The faults of the young, in his view, can only be blamed upon those who failed to provide better training for their offspring. In any case, the omission of the bishop made it possible to read this dialogue without concern for a different kind of patriarchal authority invested in the episcopacy. In both dialogues, the plain-speaking soldier framed, at each main juncture, either the consensus reached through discussion or the main points of contention left unresolved.

Clarendon explored 'education' in the broadest possible sense, beginning with the claim: 'we see mothers are much more tender of those children whom they nurse themselves, than those they billet Abroad, and there is much good proceeds from that tenderness ${ }^{6}{ }^{60}$ The speakers quickly arrived at a consensus about the need to choose servants carefully, refrain from cursing in the presence of children and the importance of posture, gait, grooming and elocution to success in later life. They agreed that demanding too much learning too soon (especially in lieu of play) harmed children, and that 'early blossoms seldom produce seasonable fruit' ${ }^{61}$ When discussing the education of boys, the soldier outlined his complaint with the grammar schools: they were overcrowded, demanded too much book learning, allowed older boys (those over sixteen) to remain too long and encouraged bad habits amongst the younger ones, provided too little opportunity for supervised recreation or training in riding, dancing, oratory or sport. Although they cannot agree on the relative advantages and disadvantages of university education over the Inns at Court or foreign travel (or even how or in which order to introduce them), the characters agreed that each path had its merits, depending on the talents of the child, his birth order and his family estates. The six 
discussed the merits of early versus late marriage, the best means of ensuring religious devotion and debated with each other over the best and worst features of four foreign destinations: France, Italy, Spain and Germany. They ended with a lively discussion about whether the theatre can possibly be as wholesome as the traditional English pursuits of hawking and hunting. Readers so disposed could very easily have used Clarendon's guidelines to choose among the first generation of English public schools that flourished until Arnold's reforms of the early Victorian period. Equipped with a copy of the Concise Description of the Endowed Grammar Schools in England and Wales (1818) and commonplace notes on Clarendon's recommendations, a nineteenth-century Englishman with Tory sympathies, imagining himself a 'person of quality', could chart a course for his sons. ${ }^{62}$

Norbert Elias, who knew Freud and trained as a psychoanalyst, appreciated the challenges in making specific texts exemplary of his 'civilizing process'. He understood that, with individual instantiations of a process by which emotions and unconscious drives are repressed and constraints internalized, individual psychopathologies doubtlessly contaminate the analysis. Only in aggregate could these be smoothed over to give a sense of change over time. ${ }^{63}$ Among Clarendon's children, evidence of what nineteenth- and twentieth-century readers would recognize as alcoholism, profligacy, despondency, melancholy and neuroticism abound - suffering no doubt engendered, or at least made worse, by the loss of their mother to death and father to exile in quick succession. Disentangling the desire to honour their father's memory from the elements of the 'civilizing process' as modelled by Elias would be impossible. Rather, Clarendon's dialogues are compelling as a 'case study' in the 'civilizing process' because they specifically addressed the role of education in the socialization of elites to their social roles, what we recognize as 'psycho-' and 'sociogenesis'. As Elias put it: 'these self-constraints, a function of the perpetual hindsight and foresight instilled in the individual from childhood in accordance with integration in 
extensive chains of action, have partly the form of conscious self-control and partly that of automatic habit. ${ }^{64}$ The ideal, as Elias described it, was 'a specific "super-ego," which endeavors to control, transform or suppress his or her affects in keeping with the social structure'. ${ }^{65}$ The Earl of Clarendon, both in his own imagination and in his reputation among both contemporaries and successive generations, perfected the ideals of moderation and selfcontrol. As he described it in his autobiography, 'he formed his manners, subdued that pride, and suppressed the heat and passion he was naturally inclined to be transported with' ${ }^{66}$ Believing one learned from the example of superiors, he claimed, 'all his friends and companions being in their quality, in their fortunes, at least in their faculties and endowments of mind, very much his superiors'. In a sense, Clarendon offered a microcosm of Elias's process of acculturation, for 'he always urged his children to follow his example in that point, making their friendships and conversation'. ${ }^{67}$ His contemporaries complimented his 'humane temper', his stoicism and sanguinity in the face of great adversity. ${ }^{68}$

His first biographer, who had no patience for Clarendon's politics or the exculpatory character of his autobiography, and even less for the royalist sympathies of his History, nonetheless concluded: 'his versatility was one of the elements of his greatness. The range of his abilities was still more extraordinary than their depth.' Lister felt that 'he might have been a more learned lawyer, a more able statesman, a more eloquent orator, a more accomplished writer, without being so remarkable a man'. Remarkable in large part because, for generations of Englishmen, Edward Hyde, Earl of Clarendon, whether they knew it consciously or not, encapsulated the chief elements of the 'civilizing process' as it unfolded in the British Isles. Although in all likelihood the dialogues were meant as advice and consolation to his sons and were not intended for publication, the attentive reader of his Two Dialogues can appreciate something both of why they offer such a compelling explication of 
the Elias' thesis and, more immediately, of why Jonathan Steinberg took such delight in his discovery of Clarendon's personality and his writings.

\footnotetext{
${ }^{1}$ The author is grateful to Mr Prateek Vijayavargia, Professor Yaacob Dweck and Ms Laura Pilsworth for helping her to secure secondary literature to update the historiographical discussion during the Covid-19 lockdown over the summer of 2020.

2 Jonathan Steinberg, "Real Authentick History" or What Philosophers of History Can Teach Us', The Historical Journal 24, no. 2 (June 1981): 454.

${ }^{3}$ Jonathan Steinberg, 'History as a "Soft Science"', European History and European Lives: 1715 to 1914. (Chantilly, VA: Teaching Company, 2003), transcript, 3-7.

${ }^{4}$ John Morrill, 'The Religious Context of the English Civil War', Transactions of the Royal Historical Society 34 (Dec. 1984): 178.

${ }^{5}$ Hugh-Trevor Roper, Edward Hyde, earl of Clarendon, a lecture delivered before the University of Oxford on 2 December 1974 to mark the tercentenary of Clarendon's death (Oxford: Clarendon Press, 1975), 28.

${ }^{6}$ Steinberg, "Real Authentick History", 465-66.

${ }^{7}$ Martine Watson Brownley, 'Introduction', in Two Dialogues: Of the Want of Respect Due Age and Concerning Education, repr. of 2nd, 1751 ed. (Los Angeles, CA: Augustan Reprint Society, 1984), $\mathrm{x}$.

${ }^{8}$ Martine Watson Brownley, Clarendon and the Rhetoric of Historical Form. (Philadelphia: University of Pennsylvania Press, 1995); Philip Hicks, Neoclassical History and English Culture: from Clarendon to Hume. (New York: St. Martin's Press, 1996).

${ }^{9}$ Perez Zagorin, 'Clarendon and Hobbes', The Journal of Modern History 57, no. 4 (Dec. 1985): 593-616; J. G. A. Pocock, The Ancient Constitution and the Feudal Law: A Study of English Historical Thought in the Seventeenth Century, new ed., with a retrospect (Cambridge: Cambridge University Press, 1987); and John Bowle, Hobbes and his Critics: A Study in Seventeenth Century Constitutionalism (London: J. Cape, 1951).

${ }^{10}$ Martin Dzelzainis, "'All things serious and sacred": Clarendon as Essayist', in Clarendon Reconsidered: Law, Loyalty, Literature, 1640-1674, ed. Philip Major (London: Routledge, 2017), 112-34.

${ }^{11}$ Martin Dzelzainis, “Undoubted Realities”: Clarendon on Sacrilege', The Historical Journal 33, no. 3 (Sept. 1990): 515-40. John E. Mason, 'Gentlefolk in the Making: Studies in the History of English Courtesy Literature and Related Topics from 1531 to 1774', (PhD diss., University of Pennsylvania, 1935), 154-55.

${ }^{12}$ Dzelzainis, "All things serious and sacred"”, 100.

13 'The Editor to the Reader', in The Miscellaneous Works of the Right Honourable Edward, Earl of Clarendon, 2nd ed. (London: Samuel Paterson, 1751).

${ }^{14}$ Trevor Roper, Edward Hyde, earl of Clarendon, 29. Edmund Burke, particularly in his Reflections on the Revolution in France (1790), is often suggested as a kind of intellectual heir to Clarendon.

${ }^{15}$ Norbert Elias, The Civilizing Process: Sociogenetic and Psychogenetic Investigations, rev. edition, ed. Eric Dunning, Johan Goudsblom and Stephen Mennell (Oxford: Blackwell Publishers, 2000).

${ }^{16}$ For confirmation of these sorts of details, see the excellent entries by Paul Seaward, 'Hyde, Edward, first earl of Clarendon', in Oxford Dictionary of National Biography (Oxford: Oxford University Press, 2004), accessed 8 October 2020, https://doi.org/10.1093/ref:odnb/14328; or the older, Sir Charles H. Firth, 'Edward Hyde,
} 
Earl of Clarendon', in Dictionary of National Biography, vol. 10 (London: Oxford University Press, 1921-1922), 370.

${ }^{17}$ Seaward, 'Hyde, Edward, first earl of Clarendon'.

${ }^{18}$ For the best account, see David L. Smith, Constitutional Royalism and the Search for Settlement (Cambridge: Cambridge University Press, 1994). A less convincing, but useful account can also be found in R. W. Harris, Clarendon and the English Revolution (London: The Hogarth Press, 1983).

${ }^{19}$ By far the most important and influential treatment is the brilliant, if highly idiosyncratic, analysis offered by Brian Wormald, Clarendon: Politics, Historiography, and Religion, 1640-1660 (1951; repr. Cambridge: Cambridge University Press, 1964). For the constitutional and legal questions, see Michael Mendle, Dangerous Positions: Mixed Government, the Estates of the Realm, and the Making of the Answer to the XIX Propositions (University: University of Alabama Press, 1985); for questions of sociability, friendship and political involvement, see Richard Ollard, Clarendon and his Friends (New York: Atheneum, 1988). Biographies of Viscount Falkland also address his 'Great Tew' circle, as do Zagorin, 'Clarendon and Hobbes', and Dzelzainis, "All things serious and sacred"'.

${ }^{20}$ For a factual account, one that remains cautious in its appraisal of Hyde, see Ronald Hutton, Charles the Second, King of England, Scotland and Ireland, (Oxford: Clarendon Press, 1989); and Hutton, The Restoration: A Political and Religious History of England and Wales, 1658-1667 (Oxford: Clarendon Press, 1985). Suffice it to say Clarendon knew Charles II at the nadir of his fortunes. For analytical and critical assessments of his role in the Restoration Settlement and political career until his fall, see Smith, Constitutional Royalism, and, most importantly, Paul Seaward, The Cavalier Parliament and the Reconstruction of the Old Regime (Cambridge: Cambridge University Press, 1989).

${ }^{21}$ Seaward, 'Hyde, Edward, first earl of Clarendon', provides a sufficient summary.

${ }^{22}$ See S. W. Singer, ed., The Correspondence of Henry Hyde, Earl of Clarendon and his brother, Laurence Hyde, Earl of Rochester; with the Diary of Lord Clarendon from 16871700, 2 vols (London, 1828), 1:650. Hereafter, Correspondence.

${ }^{23}$ See Thomas Max Safley, 'Die Fuggerfaktoren Hörmann von und zu Gutenberg: Werte und Normen einer kaufmännischen Familie im Übergang zum Landadel', in Augsburger

Handelshäuser im Wandel des historischen Urteils, ed. Johannes Burckhardt, Colloquia Augustana, vol. 3 (Berlin: Akademie Verlag, 1996). Safley uses a family chronicle to offer a portrait of the changing values and standards reflected in the occupational, educational and marriage choices of the Hörmann family of early modern Swabia in their dual existence as members of both the urban patriciate of several imperial cities and the landed aristocracy. While my account of the Hyde family has an altogether different purpose, his example emphasizes the need to preserve the nuances of these 'blended elites'.

${ }^{24}$ T. H. Lister, Life and Administration of Edward, First Earl of Clarendon; with Original Correspondence and Authentic Papers Never Before Published, 3 vols (London: Longman, Orme, Brown, Green, and Longmans, 1838), 2:489-90. Both children had been well provided for in his will of 1666 ( $£ 10,000$ to Frances in one lump sum and a pension of $£ 200$ annually for life to James) before his fall. See Ollard, Clarendon and His Friends, 348-49. ${ }^{25}$ John Spurr, 'Morley, George (1598?-1684), bishop of Winchester'; 'Sheldon, Gilbert (1598-1697), archbishop of Canterbury', in Oxford Dictionary of National Biography (Oxford: Oxford University Press, 2004), accessed 8 October 2020, https://doi.org/10.1093/ref:odnb/19285; and https://doi.org/10.1093/ref:odnb/25304. ${ }^{26}$ Ibid. Also Correspondence, 1:647.

27 'The Archbishop of Canterbury to the Bishop of Winchester', 'The Bishop of Winchester to the Archbishop of Canterbury' and 'The Archbishop of Canterbury and Bishop of Winchester's Speech to the Duke of York to Reclaim him from Popery', in Correspondence, 
1:465-71. While there is little in these letters that suggests the direct influence of Clarendon's meditations on the psalms, it is clear the three shared the same brand of High Church

Anglicanism.

${ }^{28}$ Grant Tapsell, "“a zealous Protestant”: Religion and the Political Rise and Fall of Laurence Hyde, earl of Rochester', paper given to Religious History Seminar, I.H.R., 25 May 2004. I am grateful to Grant Tapsell for a copy of the text, which I hope he will develop into a fulllength article.

${ }^{29}$ See Lister, Life and Administration, 2:562-63. The meditations on the psalms were apparently written while at Jersey; they were inadvertently shipped to Clarendon, along with the manuscript of his History in 1668. The epistolary dedication to his children is dated 1670 at Montpelier. See below, Miscellaneous Works (1751), 349.

${ }^{30}$ Most of this is covered in Sidney Lee, 'Keightley, Thomas', in Dictionary of National Biography, vol. 10 (London: Oxford University Press, 1921-1922), 1194-95. For the Isle of Wight notation, see Correspondence, 2:288. For the 1686 retreat and her drinking, see Correspondence, 1:577.

${ }^{31}$ Lee, 'Keightly, Thomas', 1195.

${ }^{32}$ Tapsell, Life and Career, 5.

${ }^{33}$ Lister, Life and Administration, 1:564.

${ }^{34}$ Miscellaneous Works (1751), Contents.

${ }^{35}$ Lister, Life and Administration, 1:565, 575.

${ }^{36}$ Seaward, 'Hyde, Edward, first earl of Clarendon', makes a similar comment in passing about the quality of the 'devotional writings,' and the Hyde brothers consulting of Sancroft as literary executors.

${ }^{37}$ Correspondence, 1: 645-50. The bulk of his personal correspondence perished in the fire mentioned above. So, the scant evidence that remains may represent a great deal more in a similar vein. See ibid., 1:170-75, for a similar meditation on his daughter's death.

${ }^{38}$ Ibid., 1:9-11. He also had to sort out his elder brother's finances. See ibid., 1:16-20. At this stage, the younger brother shows great tact in his advice to his brother. Within a year or two, it's clear the older is much the lesser member of the team.

${ }^{39}$ Ibid., 1:11.

${ }^{40}$ Ibid., 1:67. James appeared to share his brother Laurence's grave sense of humour and irony, if little of his personality otherwise.

${ }^{41}$ Ibid., 1:68.

${ }^{42}$ Ibid., 1:70.

${ }^{43}$ Harold Love, Scribal Publication in Seventeenth-Century England (Oxford: Clarendon Press, 1993), 37-39.

${ }^{44}$ Ibid., 79-82.

${ }^{45}$ Dzelzainis, “"All things serious and sacred", 102-3.

${ }^{46}$ See H. R. Polmer, et al., A Dictionary of the Printers and Booksellers who were at work in England, Scotland and Ireland from 1688 to 1725, (London: The Bibliographical Society, 1968), 234 and 271.

${ }^{47}$ Fifty-two copies of this edition survive in the collections of research libraries with an unknown number in private hands. I am particularly grateful to the Library Company of Philadelphia for allowing me to use theirs, precarious as its condition was. Edward Hyde, Earl of Clarendon, A Collection of Several Tracts of the Right Honourable Edward, Earl of Clarendon... (London: T. Woodward and J. Peele, 1727), [ESTCN53935].

${ }^{48}$ Of this edition, fifteen copies survive in research libraries. Edward Hyde, Earl of Clarendon, A Collection of Several Tracts of the Right Honourable Earl of Clarendon... (London: T. Woodward and J. Peele, 1727), [ESTCN27775]. 
${ }^{49}$ Edward Hyde, Earl of Clarendon, An Appendix to the History of the Grand Rebellion: A Collection of Several Valuable Pieces, of the Right Honourable Edward Earl of Clarendon. (London: J. Wilford, 1727). [ESTCT224745]. I am grateful to Dan Traister, Curator, Special Collections at the University of Pennsylvania for assistance in securing a fax of the frontispiece and the contents from the special collections staff of Harvard University Libraries.

${ }^{50}$ Edward Hyde, Earl of Clarendon, A Compleat Collection of Tracs, by that eminent statesman the Right Honourable Edward, Earl of Clarendon (London: C. Davis, S. Austen, S. Baker, J. Whiston, and Lockyer Davis, 1747), [ESTCN53936]. My thanks go to the Folger Shakespeare Library which owns a copy of this edition. For the printers, see Polmer, Dictionary, 10, 12, 72, 260.

${ }^{51}$ Dzelzainis, "AAll things serious and sacred", 100-101.

${ }^{52}$ Edward Hyde, Earl of Clarendon, The Miscellaneous Works of the Right Honourable Edward, Earl of Clarendon. (London: Samuel Paterson, 1751) [ESTCT53937]. Of this edition, thirty-three copies are held in research libraries, two at the University of Pennsylvania and one at the Library Company of Philadelphia. I am grateful to the curatorial staff of the Library Company of Philadelphia for confirming my conclusion that this was indeed the same type tray as the 1727 edition held in their collections.

${ }^{53}$ Polmer, Dictionary, 193.

${ }^{54}$ Edward Hyde, Earl of Clarendon, A Dialogue concerning Education (Glasgow: Robert Urie, 1764) [ESTCT128225]; A Dialogue on the want of respect due age (Glasgow: Robert Eurie, 1765) [ESTCT128224]. Very few copies, two and three respectively, of either of Urie's printings survive in research libraries.

${ }^{55}$ Polmer, Dictionary, 362.

${ }^{56}$ Edward Hyde, Earl of Clarendon, Moral Beauties of Clarendon: Compiled from his Reflections on the Psalms of David..., 2 vols (London: F. and C. Rivington, 1796). I am grateful to the Library Company of Philadelphia for permitting me to inspect these two little volumes.

${ }^{57}$ Edward Hyde, Earl of Clarendon, Essays Moral and Entertaining on the Various Faculties and Passions of the Human Mind. (London: Longman, Hurst, Rees, Orme and Brown, Paternoster-Row, 1815). I am grateful to Columbia University Libraries for making these available.

${ }^{58}$ Francis Bacon and Edward Hyde, Essays by Lords Bacon and Clarendon. Two Volumes in One: Essays, Moral, Economical and Political by Francis Bacon and Essays Moral and Entertaining by the Right Honourable Edward, Earl of Clarendon (Boston: Wells and Lilly, 1820).

${ }^{59}$ Ibid.

${ }^{60}$ Clarendon, Concerning Education, 314.

${ }^{61}$ Ibid., 318.

${ }^{62}$ Nicholas Carlisle, Concise Description of the Endowed Grammar Schools in England and Wales (London: Baldwin, Cradock and Joy, 1818).

${ }^{63}$ Elias, Civilizing Process,. 376-77.

${ }^{64}$ Ibid., 375.

${ }^{65}$ Ibid.

${ }^{66}$ Clarendon, Life, 33.

${ }^{67}$ Ibid.

${ }^{68}$ Brownley, 'Introduction', in Two Dialogues, vii. 